\title{
Frequency of temporomandibular joint dysfunction with clicking symptom due to primary molar premature loss in children aged 6-12 years old
}

\author{
Riana Hestu Laksitowati, \\ Department of Pediatric Dentistry Faculty of Dentistry Universitas Padjadjaran
}

\section{ABSTRACT}

Temporomandibular joint dysfunction with clicking symptom is sound "click" when open and close the mouth. The purpose of this study was to obtain the description of frequency of temporomandibular joint dysfunction with clicking symptom caused by premature loss of primary molar teeth in children aged 6-12 years old at SDIT Imam Bukhari. The study was a descriptive survey, 136 students as samples were taken by purposive sampling technique. Premature loss of primary molar teeth examinated by checking up the first and second primary molars upper and lower jaw using the hand mirror and explorer. Temporomandibular joint dysfunction examinated by palpation and using stethoscope. The result of this study showed that from 136 students having premature loss there are 49 students $(36,03 \%)$ had temporomandibular joint dysfunction with clicking symptom. The conclusion of this study indicates that more than one-fourth students at SDIT Imam Bukhari with premature loss of primary molar teeth had temporomandibular joint dysfunction with clicking symptom.

Key words: premature loss, TMJ dysfunction, clicking.

\section{INTRODUCTION}

The loss of primary teeth before the eruption of the permanent teeth is called the premature loss of the primary teeth. The premature loss of primary teeth is caused by trauma or carries and in several cases it is caused by congenital causes. ${ }^{1}$ Caries becomes the most frequent cause of the premature loss of primary teeth although it is not the main cause and mostly seen in children. ${ }^{2,3}$ Caries can be experienced by everyone and may expand to deeper tooth structures. ${ }^{4}$ Caries mostly happens in posterior teeth. This is caused by the anatomical form of the posterior dental occlusal part, especially for molar teeth, that have more cusps and fissures. ${ }^{5}$ leading to bigger chance of food debris and accumulation. Pit and fissure are the parts that often become carious. ${ }^{6-8}$ The primary tooth that is often lost prematurely is the lower first molar. ${ }^{9}$

A research done by Dentakusuma ${ }^{10}$ shows a quite high caries prevalence in SDIT Imam Bukhari, i.e. $84.39 \%$ with a def index of 4.87 A study by Pahlani also shows that the molar tooth premature loss prevalence in this elementary school is quite high, i.e. $57.9 \% .{ }^{11}$

The age of 6-12 years old is the period of primary teeth to permanent teeth shifting. During 
this age, a lot of physical changes occur including changes in oral and dental condition. ${ }^{2}$ The primary tooth damages due to caries may happen to children in the age of 6-12 years old due to the habit of eating sweet food containing a lot of sugar that can accelerate dental damages.

The premature loss of primary molar premature loss causes malocculsion. ${ }^{12}$ Malocclusion is any form of deviation from normal occlusion. ${ }^{13}$ Several studies show that the frequency of malocclusion in a group of children with primary tooth dental loss is higher than control group. ${ }^{14}$ The abnormal occlusion causes abnormalities leading to an abnormal stomatognatic system function, especially in the temporomandibular joint. ${ }^{15}$ The premature loss of two or more primary molar teeth causes disorders in masticatory functions and will affect the temporomandibular joint. 2,9,12 The loss of posterior dental support will increase the load in temporomandibular joint. If there are parafunctional activities (non-functional), the loss of molar support will lead to temporomandibular join deformity that will lead to abnormal joint function. ${ }^{16}$

Abnormal occlusion may cause bad habit such as one sided mastication. ${ }^{15}$ The most frequent temporomandibular joint dysfunction is caused by the one sided mastication habit. ${ }^{17}$ The habit is caused by discomfort in chewing on one side of the jaw due to caries or occlusal contact disorder leading to chewing function shifting to another side. The chewing function shifting is initially started conscously that eventually becomes unconscious habit. ${ }^{13,15}$

Temporomandibular disturbance or known as temporomandibular disorder (TMD) or Craniomandibular disorders (CMD) is a dysfunction in masticatory and mandibular system. ${ }^{6}$ The clinical symptoms accompanying temporomandibular dysfunction may be manifested in the form of joint sound described as clicking or crepitation, asymmetric or limited mandible movement and sometimes also include jaw, ear, head and face pain. ${ }^{18}$ The most frequently found symptom of the temporomandibular joint dysfunction is the joint movement sound, i.e. clicking. ${ }^{19}$

TMJ dysfunction can be experienced by children. However, children rarely complain of the symptoms. ${ }^{20,21}$ Thesymptoms of temporomandibular joint dysfunction include, among others, headache, ear pain, neck pain and tootache. Headache is the most frequently found symptom related to temporomandibular joint dysfunction ${ }^{21}$ Temporomandibular joint dysfunction is also the main cause of migrain in children. ${ }^{22}$

A study shows that there is a high prevalence of temporomandibular joint dysfunction in mixed dentition period. ${ }^{23}$ The clicking symptom is the most frequently found temporomandibular joint dysfunction seen. A study performed by Indriati ${ }^{24}$ on 410 elementary school students in Bandung City shows that 170 children (41.46\%) experienced temporomandibular joint dysfunction with clicking symptom.

Sekolah Dasar Islam Terpadu (SDIT) Imam Bukhari is one of the private elementary schools located in Sayang Village, Jatinangor sub district, Sumedang district. The school has been established since 1997 by adopting a full day school approach aimed at giving elementary education for student potential development. The students start their school day at eight in the morning and finish at three in the afternoon.

This research result is expected to give information on temporomandibular joint dysfunction frequency with clicking symptom experienced by the students of SDIT Imam Bukhari related to the primary molar premature loss both for parents and school as well as related institutions to be used as consideration in preventing primary molar premature loss and further temporomandiblar joint dysfunction.

\section{METHODS}

The type of the study performed is descriptive study using survey technique to describe the frequency of temporomandibular dysfunction with clicking symptom in children who experience primary molar premature loss at Sekolah Dasar Islam Terpadu (SDIT) Imam Bukhari. The study population includes all students who study at SDIT Imam Bukhari. The sampling is done using purposive sampling technique using the following criteria: Age 6-12 years old; Experience first molar premature loss and/or both primary teeth in upper and lower jaws; Have good general health; Have never received orthodontic treatment; Collect informed consent that has been filled and agreed by the student's parents; and Cooperative. 


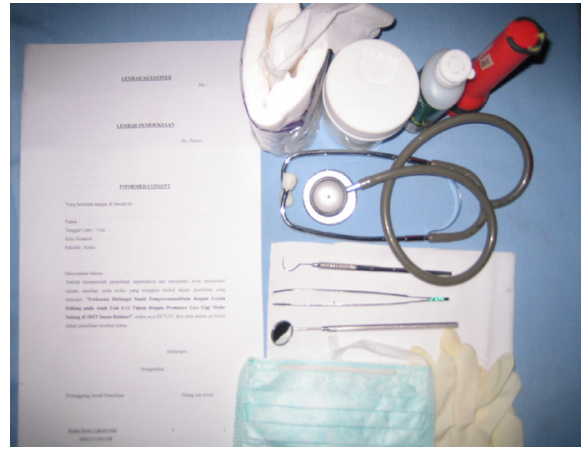

Figure 1. Materials and instruments used.

The instruments and materials for this study are: mouth mirror, dental explorer, tweezers, stethoscope, mask and gloves, flashlight, tissue and $70 \%$ alcohol for sterilizing instrument, informed consent form and examination form.

The study method used is as follows: (1) Informed consent for SDIT Imam Bukhari students were distributed to the parents to be filled and agreed 3 days before the examination; (2) Prepare the room to be used as well as the materials and instruments needed for the study; (3) Examination of primary molar premature lost is performed by asking the child to open his/her mouth and operator then examines the condition of the upper primary first and second molar of the child by using mouth mirror and dental explorer; (4) Examination of temporomandibular joint dysfunction with clicking symptom is performed by auscultation, i.e. by using stethoscope on the lateral part of each joint. The presence of "click" sound shows a clicking symptom; (5) Recording the results of the examination on the examination form and filling out questionnaires by the students assisted by the author; (6) The examination is performed in an orderly fashion starting from Class 1 to Class 6 based on students' number.

\section{RESULTS}

Primary tooth premature loss is the loss of primary teeth before the permanent substitutes erupt. The results of the study performed in SDIT Imam Bukhari shows that 136 students experience primary molar premature loss.

Primary molar premature loss increases the load imposed on the termporomandibular joint and may lead to temporomandibular joint dysfunction. The clicking symptom is the most frequently found
Table 1. Frequency of temporomandibular joint dysfunction with clicking symptom among sdit imam bukhari students who experience premature loss.

\begin{tabular}{ccc}
\hline Condition & (n) & (\%) \\
\hline Clicking & 49 & 36.03 \\
No clicking & 87 & 63.97 \\
\hline Total & 136 & 100 \\
\hline
\end{tabular}

Table 2. Frequency of temporomandibular joint dysfunction with clicking symptom in sdit imam bukhari students based on the number of primary molar teeth that experience premature loss.

\begin{tabular}{|c|c|c|}
\hline Cliking & (n) & (\%) \\
\hline Opening & 17 & 34.69 \\
\hline Closing & 25 & 51.02 \\
\hline Resiprocal & 7 & 14.29 \\
\hline Total & 49 & 100 \\
\hline
\end{tabular}

temporomandibular joint dysfunction. Table 1 shows the frequency of temporomandibular joint dysfunction with clicking symptom among SDIT Imam Bukhari students who experience primary molar premature loss.

The study results show that out of 136 students who experience molar premature loss, 49 students or $36.03 \%$ experience temporomandibular joint dysfunction with clicking symptom while 87 students or $63.97 \%$ do not experience clicking.

Temporomandibular joint dysfunction may happen in the premature loss of 1 tooth, 2 teeh, 3 teeth and even all molars. Table 2 . show the distribution of students who experience temporomandibular joint dysfunction based on the number of primary molars that experience premature loss.

Temporomandibular joint dysfunction with clicking symptom can be experienced during opening the mouth, closing the mouth or opening and closing the mouth (reciprocal). shows that clicking among SDIT Imam Bukhari students mostly happened during mouth closing, i.e. happens in 25 students or $51.02 \%$.

\section{DISCUSSION}

The premature loss of primary teeth is the loss of primary teeth before the substitute teeth erupt. ${ }^{25}$ The primary molar premature loss is that 75 SDIT Imam Bukhari students experience 
molar premature loss due to caries. Caries is most frequently found in posterior teeth. This is caused by the anatomical form of the posterior teeth, especially because the posterior teeth have more cusps and fissures ${ }^{5}$ leading to bigger possibility of food debris and accumulation. Pit and fissure are the parts that often become carious. ${ }^{6-8}$

One of the methods to maintain oral hygiene is by toothbrushing. The objective of tootbrushing is to remove plaque and prevent caries. Health experts suggest a regular toothbrushing of twice a day, in the morning and afternoon, or after meals. ${ }^{8}$ The questionnaire results shows that out of 273 SDIT Imam Bukhari students, 149 students have maintained their dental health by brushing the teeth twice a day.

The premature loss of primary molars may lead to masticatory function disturbance. The loss of posterior teeth increase load in the temporomandibular joint. ${ }^{16}$ The results of the research shows that out of 136 SDIT Imam Bukhari students who experience primary molar premature loss, 49 students (36.03\%) experience temporomandibular joint dysfunction with clicking symptom and 87 students $(63.97 \%)$ do not show clicking (Table 1). Clicking symtom is the most frequent TMJ dysfunction seen. ${ }^{19}$

The dental premature loss may lead to the habit of one sided chewing. The habit is caused by the discomfort of chewing on one side of the jaw due to caries or disorder in occlusal contact that eventually become unconscious habit. ${ }^{13,15}$ The results of the questionnaire show that out of 49 students who experience temporomandibular joint dysfunction with clicking symptom, 34 students have a habit of one sided chewing. The one sided chewing is also found in patients with temporomandibular pain in one side of the jaw. The patient prefers to chew on the side that is painful because there is more pressure on the balancing condyle that the working condyle. ${ }^{13}$

Temporomandibular joint dysfunction may happen in the premature loss of 1 tooth, 2 teeh, 3 teeth and even all molars. A premature loss of two or more primary molars will disturb the masticatory function and affect temporomandibular joint. 2,9 The results of the study show that the temporomandibular joint dysfunction with clicking symptom mostly happens in one molar loss, i.e. in
16 students or $32.65 \%$ (Tab. 2).

Clicking is the "click" sound in the joints that may occur during opening or closing the mouth and is referred as single click or during opening and closing the mouth and is referred as reciprocal clicking. ${ }^{21}$ The study results show that most clickings happen during closing, i.e. 25 students or $51.02 \%$.

The temporomandibular joint dysfunction may happen to children but children rarely complain about the symptoms. ${ }^{20,21}$ The problem in the temporomandibular joint starts when a child experiences headache. The pain due to headache is not common among children. Headache is caused by overloading the system. ${ }^{26}$ Temporomandibular joint dysfunction has symptoms like headache, ear pain, neck pain, and dental pain. ${ }^{22}$ The results of the questionnaire show that out of 49 students who experience clicking, 35 students often experience headache, 6 students often experience pain in the jaw and joint area and the surrounding area and 5 students feel pain when the lower jaw is moved. The movement that frequently causes pain experienced by 3 students is the movement of lower jw to the right side.

The masticatory system activation is divided into 2 types, functional activity type such as chewing, speaking and swallowing and parafunctional (non-functional) activity type that relates to unconscious bad habit such as finger sucking, tongue thrust, pencil biting, and abnormal occlusion. If there is parafunctional activities, the loss of molar support will cause temporomandibular joint deformity leading to abnormal joint function. ${ }^{16,21}$ The results of the questionnaire show that out of 49 students who experience temporomandibular joint dysfunction with clicking symptom, 7 of them have the habit of thumb sucking, 19 have pencil or nail biting habit, 5 have mouth breathing habit and 8 have tongue thrust habit.

Teeth is a part of oral cavity that have an important function. If the teeth is not maintained, premature dental loss may happen. The premature loss of teeth can cause masticatory function disturbance which is the starting point of the temporomandibular joint dysfunction. One of the forms of the most frequently found temporomandibular dysfunction is clicking. 


\section{CONCLUSION}

Based on the study results on SDIT Imam Bukhari students aged 6-12 years old, it is concluded that more than a quarter of students who experience primary molar premature loss have temporomandibular joint dysfunction with clicking symptom (36.03\%).

\section{SUGGESTION}

It issuggested thatimprovement of knowledge on oral and dental health especially on primary molar premature loss and temporomandibular dysfunction is performed through periodic education sessions at SDIT Imam Bukhari. It is expected that with the periodic education on dental health especially on caries will help to control primary molar premature loss at SDIT Imam Bukhari and prevent further temporomandibular joint dysfunction. It is recommended that treatment for students with temporomandibular joint dysfunction with clicking symptom due to primary molar premature loss should be given so that further temporomandibular joint dysfunction can be avoided.

\section{REFERENCES}

1. Finn SB. Clinical pedodontics. $4^{\text {th }}$ ed. Philadelphia: W.B. Saunders Co.; 2003. p. 21, 45,274.

2. Moyers RE. Handbook of orthodontics. $4^{\text {th }}$ ed. Chicago: Year Book Medical Publishers Inc.; 1988. p. 159-61.

3. Pinkham JR, et al. Pediatric dentistry-infancy through adolescence. $4^{\text {th }}$ ed. St Louis: Elsevier Saunders. 2005. p. 423-4,463,471

4. Yani RWE. Hubungan pola menyikat gigi dengan karies gigi. Indonesian J Dentistry 2005;12 (1):15-8.

5. Harshanur IW. Anatomi gigi. Jakarta: Penerbit Buku Kedokteran EGC; 1991. p. 21,26-7.

6. Koch G, Poulsen S. Pediatric dentistry-A clinical approach. Copenhagen: Munksgaard; 2001. p. 196,411.

7. Welbury RR. Pediatric dentistry. New York: Oxford University Press. 2001. p. 148.

8. Wikipedia. Tooth. 2007. [cited 2007 Jul 30]. Available from:http://www.wikipedia.com.
9. Farsi NMA, Alamoudi N. Relationship between premature loss of primary teeth and the development of temporomandibular disorders in children. International J Pediat Dentistry 2000;10:57-62.

10. Dentakusuma. Prevalensi karies dan indeks def Siswa Sekolah Dasar Islam Terpadu (SDIT) Imam Bukhori Desa Sayang Kecamatan Jatinangor Kabupaten Sumedang. Skripsi. Bandung: Fakultas Kedokteran Gigi Universitas Padjadjaran. 2005

11. Pahlani N. Prevalensi premature loss gigi molar pertama dan molar kedua sulung rahang atas dan rahang bawah pada siswa usia 6-12 Tahun. Skripsi. Bandung: Fakultas Kedokteran Gigi Universitas Padjadjaran; 2005.

12. Alamoudi N. The prevalence of crowding, attrition, midline discrepancies, and premature tooth loss in the primary dentition of children in Jeddah, Saudi Arabia. J Clin Pediatric Dentistry 1999;24(1):53-58.

13. Ramfjord SP, Ash MM. Occlusion. $3^{\text {rd }}$ ed. Philadelphia: W.B. Saunders Co.; 1983. p. 1457,248-9,191-7.

14. Magnusson BO. Pedodontics-A systematic approach. Copenhagen: Munksgaard. 1981. p. 261.

15. Shore NA. Occlusal equilibration and temporomandibular joint dysfunction. Philadelphia: JB Lippincott Co.; 1959. p. $38,40,97,130$

16. Pertes RA, Gross SG. Clinical management of temporomandibular disorders and orofacial pain. Illinois: Quintessence Publishing Co, Inc. 1995. p. 1-6,9,69,72-9.

17. Ogura T. Epidemiologic research about TMJ dysfunction syndrome at teenager. The $\mathrm{J}$ of Clin Ped Dentist. 1990;16:1.

18. McNeill C. Craniomandibular disorders, guidelines for evaluation, diagnosis, and management. Chicago: Quintessence Publishing Co, Inc.; 1993. p. 7,21-3.

19. Mayoclinic. Temporomandibular joint disorders. 2005. [cited 2007 Feb 05]. Available from:http://www.mayoclinic.com.

20. Christiansen EL, Thompson JR. Temporomandibular joint imaging. St Louis: Mosby Year Book, Inc.; 1990. p. 14.

21. Okeson JP. Management of temporomandibular disorders and occlusion. $4^{\text {th }}$ ed. St Louis: 
Mosby Year Book, Inc. 1998. p. 6-23,935,152,158,161,193-9,221.

22. Bargamian K. TMJ dysfunction is major cause of headaches and pain in children. 2004. [cited 2007 Jul 30]. Available from:http://www. crestwooddentalandtmj.com/index.html.

23. Sari S. et al. Temporomandibular joint dysfunction and occlusion in the mixed and permanent dentition. J Clin Ped Dentist. 1999;24(1):59-62.

24. Indriati S. Gambaran frekuensi kebiasaan mengunyah satu sisi pada anak-anak yang mengalami disfungsi sendi temporomandibula dengan gejala kliking di sekolah dasar Kotamadya Bandung. Skripsi. Bandung: Fakultas Kedokteran Gigi Universitas Padjadjaran. 2000.

25. Salzmann JA. Orthodontics principles and prevention. Philadelphia: J.B. Lippincott Co.; 1957. p. 292.

26. Gillum RS, Bowling JR. Headaches in children. 2004. [cited 2007 Jul 30]. Available from: Available at http://www. friendlysmile.net. 